\title{
Novel KRIT1/CCM1 heterozygous nonsense mutation (c.715 C>T) associated with cerebral and cerebellar cavernous malformations in a paediatric patient
}

\author{
Dillon Y Chen, John Ross Crawford
}

Department of Neurosciences and Pediatrics, University of California San Diego, San Diego, California, USA

\section{Correspondence to} Dr John Ross Crawford, jrcrawford@ucsd.edu

Accepted 10 July 2018

\section{DESCRIPTION}

A 4-year-old Hispanic boy with no significant history presented to the emergency room with 4 days of headache, nausea, vomiting and gait abnormality. Physical exam was significant for cerebellar symptoms. MRI of the brain showed multiple foci of susceptibility, which are suggestive of cavernous malformations with evidence of recent haemorrhagic in the largest cerebellar lesion (figure 1). Magnetic resonance angiogram and MRI of the spine did not show additional lesions. Genetic sequencing revealed a novel heterozygous nonsense nucleotide transition (c.715C > T;pQ239X) of the CCM1/KRIT1 gene. This mutation predicted a premature stop codon and is expected to be pathogenic. No family history of cavernous malformation was reported for this patient.

Cerebral cavernous malformations (CCMs) are vascular lesions that affect $0.5 \%$ of the population. Three genetic loci-CCM1, CCM2 and CCM3are responsible for nearly $90 \%$ of all familiar cavernous malformations. ${ }^{1}$ Mutations in the CCM genes are hypothesised to lead to compromised endothelium integrity and abnormal angiogenesis, resulting in vascular malformation. ${ }^{2}$ Hispanic Americans, like our patient, have a 20 -fold to 100 -fold

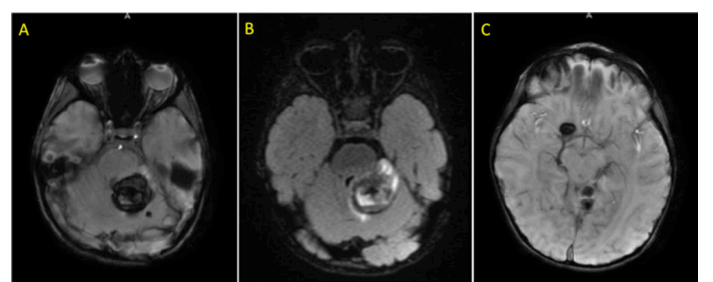

Figure $1 \mathrm{MRI}$ of the brain demonstrates a large heterogeneous lesion in the left cerebellar hemisphere with associated oedema (A: Swan sequence; B: T2 fluid attenuation inversion recovery sequence), and additional lesions, including in the right posterior inferior frontal lobe (C: Swan sequence). increase in risk compared with the general population, and a well-documented founder mutation (c.1363C > T;pQ455X) has been reported. ${ }^{3}$ Only $20 \%-30 \%$ of patients with CCM are symptomatic. ${ }^{1}$ While CCM has been well described in adults, the natural history of CCM progression in the paediatric population is not well known; the mean age of clinical onset is 29.7 years. $^{2}$ This CCM1/KRIT1 mutation, identified in our patient, has never been reported. Thus, although less prevalent, in a paediatric patient with characteristic neuroimaging findings of CCM, genetic testing should be considered.

\section{Learning points}

- Patients with cerebral cavernous malformations can present with seizures, stroke, headaches or haemorrhage.

- Genetic testing should be considered if the neuroimaging demonstrates lesions suggestive of cerebral cavernous malformations.

Contributors JRC and DYC were responsible for the design, acquisition and interpretation of the data, and writing of the case report. Both authors have reviewed and approved this submission.

Funding The authors have not declared a specific grant for this research from any funding agency in the public, commercial or not-for-profit sectors.

Competing interests None declared.

Patient consent Parental/guardian consent obtained.

Provenance and peer review Not commissioned; externally peer reviewed.

\section{REFERENCES}

1 Choquet H, Pawlikowska L, Lawton MT, et al. Genetics of cerebral cavernous malformations: current status and future prospects. J Neurosurg Sci 2015;59:211-20.

2 Cox EM, Bambakidis NC, Cohen ML. Pathology of cavernous malformations. In: Spetzler RF, Moon K, Almefty RO, eds. Handbook in clinical neurology. New York: Elsevier, 2017:267-77.

3 Sahoo T, Johnson EW, Thomas JW, et al. Mutations in the gene encoding KRIT1, a Krev-1/rap1a binding protein, cause cerebral cavernous malformations (CCM1). Hum Mol Genet 1999;8:2325-33. 
Copyright 2018 BMJ Publishing Group. All rights reserved. For permission to reuse any of this content visit http://group.bmj.com/group/rights-licensing/permissions.

BMJ Case Report Fellows may re-use this article for personal use and teaching without any further permission.

Become a Fellow of BMJ Case Reports today and you can:

- Submit as many cases as you like

- Enjoy fast sympathetic peer review and rapid publication of accepted articles

Access all the published articles

- Re-use any of the published material for personal use and teaching without further permission

For information on Institutional Fellowships contact consortiasales@bmjgroup.com

Visit casereports.bmj.com for more articles like this and to become a Fellow 